\title{
Correction to: Molecular characterization of Tomato leaf curl virus infecting hollyhock (Alcea rosea L.) in India
}

\author{
K. V. Ashwathappa ${ }^{1} \cdot$ V. Venkataravanappa ${ }^{1,2}$ - C. N. Lakshminarayana Reddy ${ }^{3} \cdot$ M. Krishna Reddy $^{1}$
}

Published online: 28 May 2020

(c) Indian Phytopathological Society 2020

Correction to: Indian Phytopathology (2020) 73:339-347 https://doi.org/10.1007/s42360-020-00221-2

The original version of this article unfortunately contained a mistake. The spelling of the K. V. Ashwathappa name was incorrect.

Publisher's Note Springer Nature remains neutral with regard to jurisdictional claims in published maps and institutional affiliations.

The original article can be found online at https://doi.org/10.1007/ s42360-020-00221-2.

V. Venkataravanappa

venkatrajani@gmail.com

$\triangle$ C. N. Lakshminarayana Reddy

cnlreddy@gmail.com

1 ICAR-Indian Institute of Horticultural Research, Hessaraghatta Lake PO, Bangalore, Karnataka 560089, India

2 Division of Plant Pathology, Central Horticultural Experiment Station, ICAR-Indian Institute of Horticultural Research, Chettalli, Madikeri (District), Bangalore, Karnataka 57124, India

3 Department of Plant Pathology, College of Agriculture, University of Agricultural Sciences, GKVK, Bangalore, Karnataka 560065, India 